\title{
COMPARATIVE, MULTI-PARAMETER MODELLING, AT A BASINAL AND SUB-BASINAL LEVEL, FOR FLOOD VULNERABILITY, IN TECUCEL WATERSHED
}

DOI: http://dx.doi.org/10.18509/GBP.2018.60

UDC: 627.532:[528.47:004.4(498)

\author{
Andrei Enea ${ }^{1,2}$ \\ Liviu-Marian Albu ${ }^{1}$ \\ Marina Iosub ${ }^{1,2}$ \\ Andrei Urzica ${ }^{1}$ \\ ${ }^{1}$ Alexandru Ioan Cuza University of Iasi, Faculty of Geography and Geology, Department of \\ Geography, Bd. Carol I 20A, 700505, Iasi, Romania \\ ${ }^{2}$ Integrated Center of Environmental Science Studies in the North Eastern Region - \\ CERNESIM, 11 Carol I, 700506,"Alexandru Ioan Cuza" University of Iasi, Romania
}

\begin{abstract}
Of all phenomena which lead, through their manifestation, to material damage and loss of human lives, floods are the most devastating. They present a high degree of danger, both in frequency and intensity, but also by the high value of the damage produced. Romania has faced numerous floods in the past decades, of which the ones that took place in the Eastern region are of most significance in Siret watershed and Prut-Barlad river basins. To prioritize the interventions, the deployment of forces, as well as funds for flood defenses, first the zones and the sub-basins which are the most vulnerable must be identified. The purpose of this work is to develop an analysis at a sub-basinal level, which will take into consideration the most important morphometric parameters that are influencing floods, to obtain a comparative, relevant and understandable result, in order to achieve several cartographic materials that are easy to interpret and present to the authorities capable to intervene in such situations. The proposed model can be applied to any hydrographic basin that has a sufficiently detailed digital elevation model (DEM), in order to generate significant results.
\end{abstract}

Keywords: drainage basin, flood, GIS, multi-parameter, vulnerability

\section{INTRODUCTION}

Flood vulnerability assessment represents a complex analysis, that is based on a variety of techniques and methodologies, which integrates the triggering factors of this phenomenon, by using GIS implementation [1], [2]. Flooding represents an overflow of water, covering areas which are usually located in dry conditions, and occur due to factors such as heavy rain, low topographical area, riverbank erosion etc. [3], [4].

These phenomena can occur due to a series of factors such as hydrological, geomorphological, climatic and last but not least, anthropogenic factors, the latter having the possibility to be, at the same time, the cause and, in some cases, an important factor in the destructiveness of such phenomena [3], [5]. Depending on demographic and economic pressure and demands, human settlements have expanded over areas vulnerable to hydrological risks [3], [4], [6]. 
In the case of this study, the elaboration of cartographic materials that can better illustrate the hydrological vulnerability has the main purpose of identifying the areas and the subbasins which have a certain degree of vulnerability to hydrological risk in order to highlight regions where the authorities could intervene in case of necessity [5].

\section{STUDY AREA}

Tecucel river drainage basin is located in the South-Eastern part of Romania, at the contact between two geographical areas, namely the Moldavian Plateau in the North and the Romanian Plain in the South, the basin originating in the Southern tip of Tutova Hills. In this area, the basin overlaps 3 landscape sub-units: Virlanesti Hill in the North, Tecuciului Plain in the Central, Southern and Western side, and Barlad river meadow in the South-Eastern part (Fig. 1).

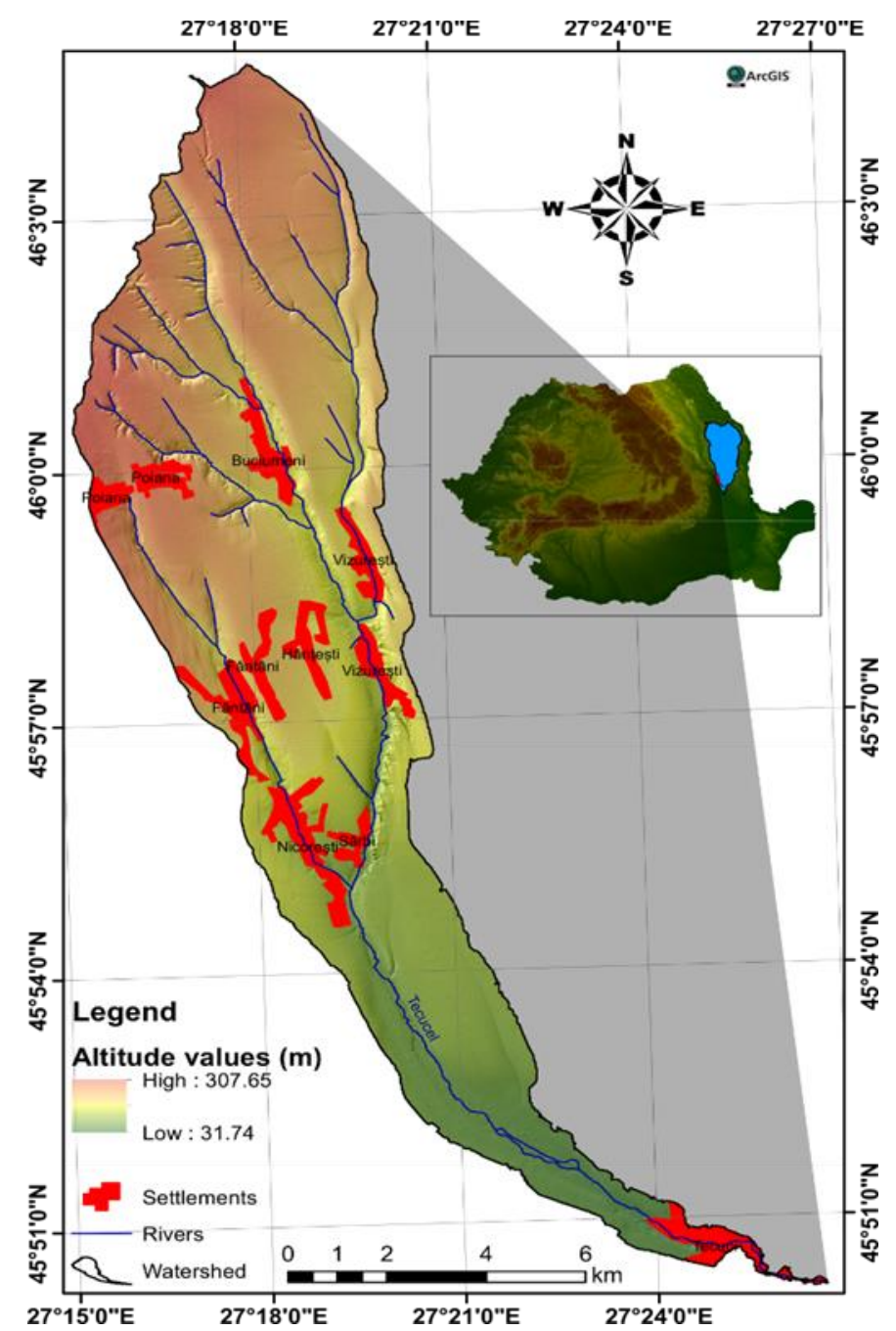

Figure 1. Geographical location of Tecucel River basin on Romanian territory

Tecucel drainage basin is a component of the Barlad river basin, being a right-side tributary with an area of $112 \mathrm{~km}^{2}$ and a length of $24 \mathrm{~km}$. The hypsometry of the area is characterized by a maximum altitude of $307.8 \mathrm{~m}$ in the Northern part, in Ploscuteni Hill, and a minimum altitude of $32.5 \mathrm{~m}$ at the confluence with the river tributary, in the Southern part of Tecuci City [7]. 
In terms of relief, the study area is represented by a hilly side in the North and Central part of the basin, mainly with low slope values ranging from 0-3 to 3-15 degrees. Although the area is mainly represented by relatively low slope values, given the geomorphology and soils, the terrain allowed the formation of a system of ravines with very steep slopes, which, during periods with high rainfall, they manage to direct the precipitation water downstream into the main channel, suddenly raising the river flow. In terms of hydrology, Tecucel drainage basin has a Circularity Ratio of 0.123 and an Elongation Ratio of 0.281 , oriented on a NW-SE direction, the upper and middle course containing a series of semi-permanent tributaries that flow approximately parallel to the main watercourse, all of them being collected downstream of Nicoresti locality.

Based on the generated drainage network in GIS environment by using a LiDAR Digital Elevation Model of 1-meter resolution, Tecucel River is, according to the Horton-Strahler hydrographic network classification, a river of order 4, in Barlad drainage basin. Given the location and the hydrological characteristics, the flooding potential of Tecucel River was highlighted in the last decade, after the flood from 5-7 September 2007, when Tecuci City was flooded [8].

In terms of administrative borders, Tecucel catchment area is located at the contact between Vrancea and Galati counties, being separated by Siret Valley and it extends over the territory of 6 settlements: Ploscuteni, Brahasesti, Buciumeni, Poiana, Nicoresti and Tecuci City at the confluence.

\section{MATERIALS AND METHODS}

Flood vulnerability assessment at basinal and sub-basinal level was possible by using a number of hydro-morphometric parameters which pose an important role in causing floods in hydrological drainage basins. When working with methodologies that imply the use of hydro-morphometric parameters in a GIS environment, it is very important that the used data is of high resolution, thus assuring more accurate results [9], [10]. This analysis is based on the use of a LiDAR digital elevation model, with a resolution of $1 \mathrm{~m}$, the access to such dataset being provided by the Regional Water Administration Prut-Barlad, Iasi. The factors considered to be the most representative in this analysis which that were taken into account are: Circularity Ratio $(R c)$, Elongation Ratio $(R e)$, Drainage Density $(D)$, Stream Frequency $(F s)$, Relief Ratio $(R h)$, Ruggedness $(R n)$ and Bifurcation Ratio $(R b)$ [5], [11-25]. These parameters are the most relevant for our study and for a better understanding of how the terrain characteristics influence the runoff behavior a brief description is important (Table 1).

The relief ratio plays an important role in drainage. The higher the relief, the steeper the slopes, thus the greater the energy available to move flows through the catchment. Watersheds with the highest relief ratio have shorter lag time and time of rise, as well as higher peaks and flow velocities, thus high values indicate a higher flash flood risk. The circularity ratio is representative due to the importance of the shape of the watershed in drainage. This means that if a basin has a more rounded form, the water flow from a heavy rainfall would reach the main channel at the same time, causing a high peak flood downstream. The ratio is equal to 1 , when the basin shape is a perfect circle, 0.785 when the shape is a square, and decreases when the basin becomes elongated. Thus, small values indicate a lower flash flood risk [26]. The elongation ratio has important hydrological consequences because, in contrast to more circular catchments, precipitation delivered during a heavy rainfall in highly elongated basins has to travel a longer distance, 
thus implying a small flood risk. Flood risk is also influenced by the roughness number, through high values, which show small but steep values to be prone to higher flash flood risk than wider valleys with lower relief but with same drainage density.

Table 1. Used morphometric parameters in the flood vulnerability analysis

\begin{tabular}{|c|c|c|c|}
\hline No. & $\begin{array}{l}\text { Morphometric } \\
\text { parameters }\end{array}$ & Formula & Abbreviations \\
\hline 1 & Circularity Ratio & $R_{c}=\frac{4 \pi * A}{P^{2}}$ & $\begin{array}{l}\mathrm{R}_{\mathrm{c}}=\text { Circularity Ratio; } \mathrm{A}=\text { Area of watershed } \\
\pi=3.14159\end{array}$ \\
\hline 2 & Elongation Ratio & $R_{e}=\frac{1}{L_{b}} \sqrt{\frac{4}{\pi} A}$ & $\begin{array}{l}\mathrm{R}_{\mathrm{e}}=\text { Elongation Ratio; } \mathrm{A}=\text { Area of watershed; } \\
\pi=3.14159\end{array}$ \\
\hline 3 & Drainage Density & $D=\frac{L}{A}$ & $\begin{array}{l}\mathrm{D}=\text { Drainage Density; } \mathrm{L}=\text { Total length of } \\
\text { streams; } \mathrm{A}=\text { Area of watershed }\end{array}$ \\
\hline 4 & Stream Frequency & $F_{S}=\frac{N}{A}$ & $\begin{array}{l}\mathrm{F}_{\mathrm{s}}=\text { Stream Frequency; } \mathrm{N}=\text { Total number of } \\
\text { streams; } \mathrm{A}=\text { Area of watershed }\end{array}$ \\
\hline 5 & Relief Ratio & $R_{h}=\frac{B_{h}}{L_{b}}$ & $\begin{array}{l}\mathrm{R}_{\mathrm{h}}=\text { Relief Ratio; } \mathrm{B}_{\mathrm{h}}=\text { Basin relief; } \\
\mathrm{L}_{\mathrm{b}}=\text { Basin length }\end{array}$ \\
\hline 6 & $\begin{array}{l}\text { Ruggedness } \\
\text { Number }\end{array}$ & $R_{n}=B_{h} * D_{d}$ & $\begin{array}{l}\mathrm{R}_{\mathrm{n}}=\text { Ruggedness Number; } \mathrm{B}_{\mathrm{h}}=\text { Basin relief; } \\
\mathrm{D}=\text { Drainage density }\end{array}$ \\
\hline 7 & Bifurcation Ratio & $R_{b}=\frac{N_{u}}{N_{u+1}}$ & $\begin{array}{l}R_{b}=\text { Bifurcation Ratio; } N_{u}=\text { Total number of } \\
\text { stream segment; } N_{u+1}=\text { Number of segment of } \\
\text { next higher order }\end{array}$ \\
\hline
\end{tabular}

In the case of drainage density, it can affect the shape of a river's hydrograph during a rain storm. For example, the high density of a stream network often has a hydrograph characterized by a quick rise and a steep fall, because the storm water can flow through multiple channels into the main channel, meaning a rapid flow of a high volume of precipitation water. A higher density means a potential high risk to flooding while a low density means a low flood risk.

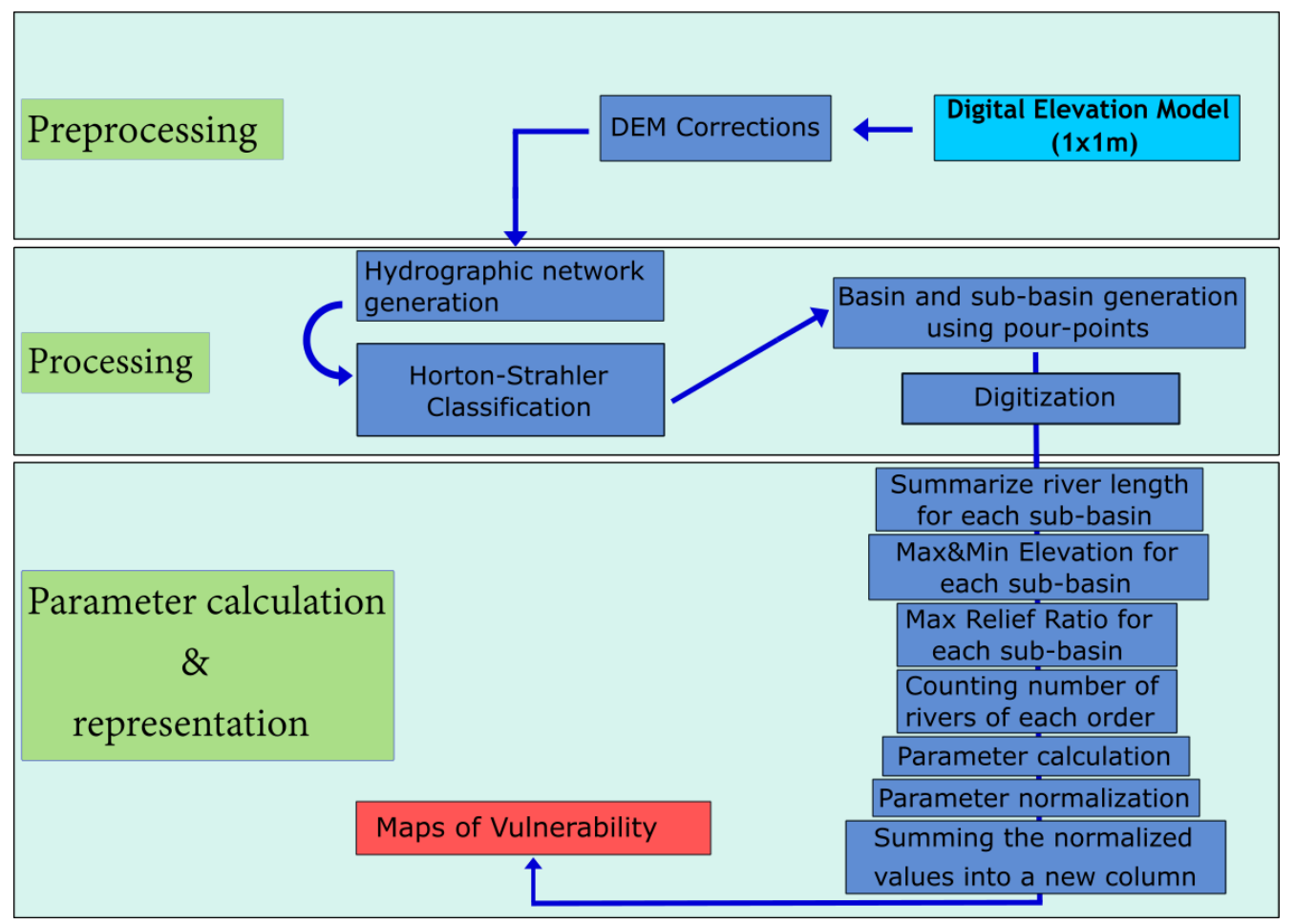

Figure 2. Methodological workflow for the analysis 
Stream frequency is directly connected with drainage density. The presence of a higher number of streams in a sub-basin means multiple channels where the water can drip and eventually concentrate in a single stream. Hence, the greater the frequency, the greater the flood risk. Finally, the bifurcation ratio is subordinate to geomorphological factors, as the ratio is higher in intensely fragmented regions and lower in flat regions and to the number of streams. If the ratio is low, there is a higher chance of flooding, as the water will be concentrated in one channel rather than spread out [27].

The necessary layers for the output of the analysis are the sub-basin layers, which help calculate the already mentioned parameters. The first step of the analysis is comprised of the elimination of small gaps from the elevation data. This was achieved by using Flow Direction, Sink and Fill tools in ArcMap 10.4 to identify and correct the found errors. In order to create the sub-basins layers, it was first necessary to generate the drainage network. This step was made automatically, by using a series of functions from Hydrology Toolset in ArcMap 10.4 like Flow Direction and Flow Accumulation. A raster query was necessary to be applied on the Flow Accumulation raster by using Raster calculator, to select only the relevant generated values referring to the river network. For this reason, the selected cells were those with values above 60000. The resulted raster was then converted to vector file, preparing the next step of generating the sub-basins. Because Tecucel River is classified after Horton-Strahler as being of order IV, there were created 3 layers with the sub-basins of rivers of each order. This process was accomplished by using pour-points at the confluence of each river with the next higher order river and by applying the Watershed function, thus resulting the necessary subbasins for which the vulnerability scores were later calculated (Fig. 2). Based on the necessary raster and vector layers, the parameters taken into account were calculated and normalized using the Feature Scaling method, which implies the ranging of values between 0 and 1 , using the formula:

$$
x_{n}=\frac{(x-\min )}{(\max -\min )}
$$

In order to generate the flood vulnerability maps, all the normalized values obtained from the calculation of the morphometric parameters had to be summed. For this step, a new column was created in the Attribute Table of each sub-basin layer and the value of the normalized parameters were added together, thus resulting the values of vulnerability to flood for each sub-basin in each layer. The cartographic representation of the flood vulnerability follows a classification using 5 classes, spanning from very low to very high vulnerability.

\section{RESULTS AND DISCUSSIONS}

As a final step, using the parameters mentioned in Table 1, maps showing the vulnerability to floods were generated (Figs. 3, 4). The colors ranging from dark green to red were chosen, to facilitate the understanding of the possible intensity of the vulnerability of floods, dark green signifying very low vulnerability, whereas red marks areas with very high vulnerability. Based on the analysis, a number of 83 sub-basins of order I were generated, 14 sub-basins of order II and 3 sub-basins of order III. The flood vulnerability map for the sub-basins of order I of Tecucel River indicates that $14.45 \%$ of the sub-basins have a very high vulnerability, $20,48 \%$ have a high vulnerability, $31.32 \%$ have a medium vulnerability, $27.71 \%$ have a low vulnerability and $6.02 \%$ have a very 
low vulnerability to floods. Concerning the sub-basins with a very high vulnerability, most of them are right side tributaries of Tecucel River, in the upper and middle course. The vulnerability scores in this analysis vary according to the input each parameter had on the final score. Thus, the very high vulnerability can be explained by the high values of some parameters like Relief Ratio and low values of Circularity Ratio, Elongation Ratio and Ruggedness Number. Because in the upper and middle course of the river, the terrain is more prominent, with hills, valleys and ravines, this morphometric characteristic translates into higher values of flood vulnerability. The sub-basins with a medium and low vulnerability are the most widespread, being generated both upstream and downstream. The classification of these basins according to the relationship between relief and parameters could be explained by the hydrological characteristics like Elongation Ratio or Relief Ratio. The sub-basins with very low vulnerability represent the least of the drainage basin surface, being located in smoother areas with low slope values. In this situation, the values of the parameters are very similar, given the resulted low values, the vulnerability to flood being very low.

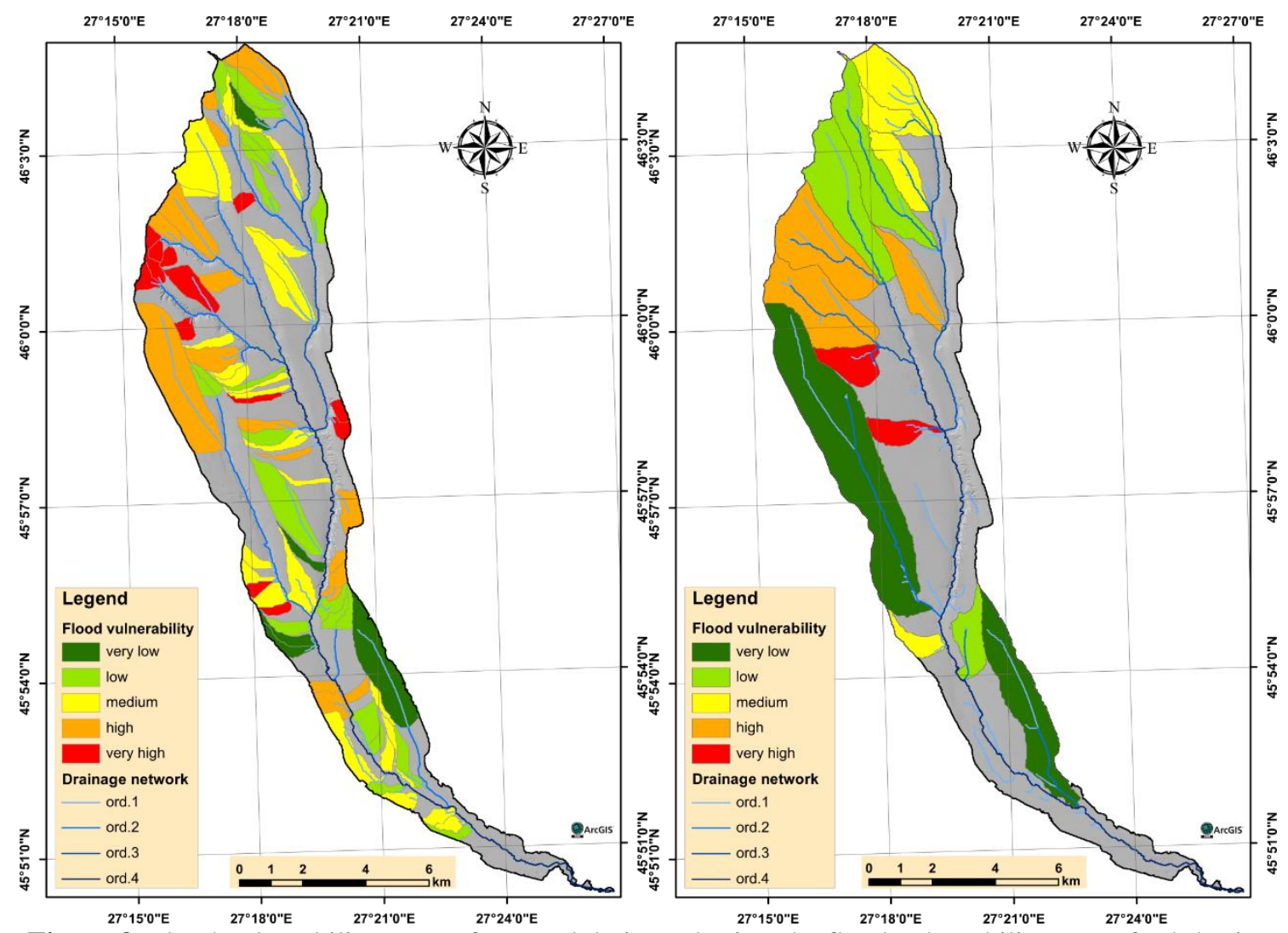

Figure 3. Flood vulnerability maps of Tecucel drainage basin. The flood vulnerability map of sub-basins of order I (left); The flood vulnerability map of sub-basins of order II (right)

The situation for the vulnerability to flood concerning the sub-basins of order II is clearer, 14 sub-basins being generated, classified from very high vulnerability to very low vulnerability. The fact that the most susceptible sub-basins to flood vulnerability, those with very high and high vulnerability, are localized in the upper part of the basin can be observed. The morphology of the land can allow a flash flood to happen, in the last years several cases of flash floods being reported by the residents of the settlements located in these sub-basins, meaning that the result is significantly accurate. Considering the subbasins with medium vulnerability, they do not pose immediate threat, because there are 
no settlements located in that area. But considering the input these sub-basins can have in case of a storm, their output can be complementary to the areas located downstream.

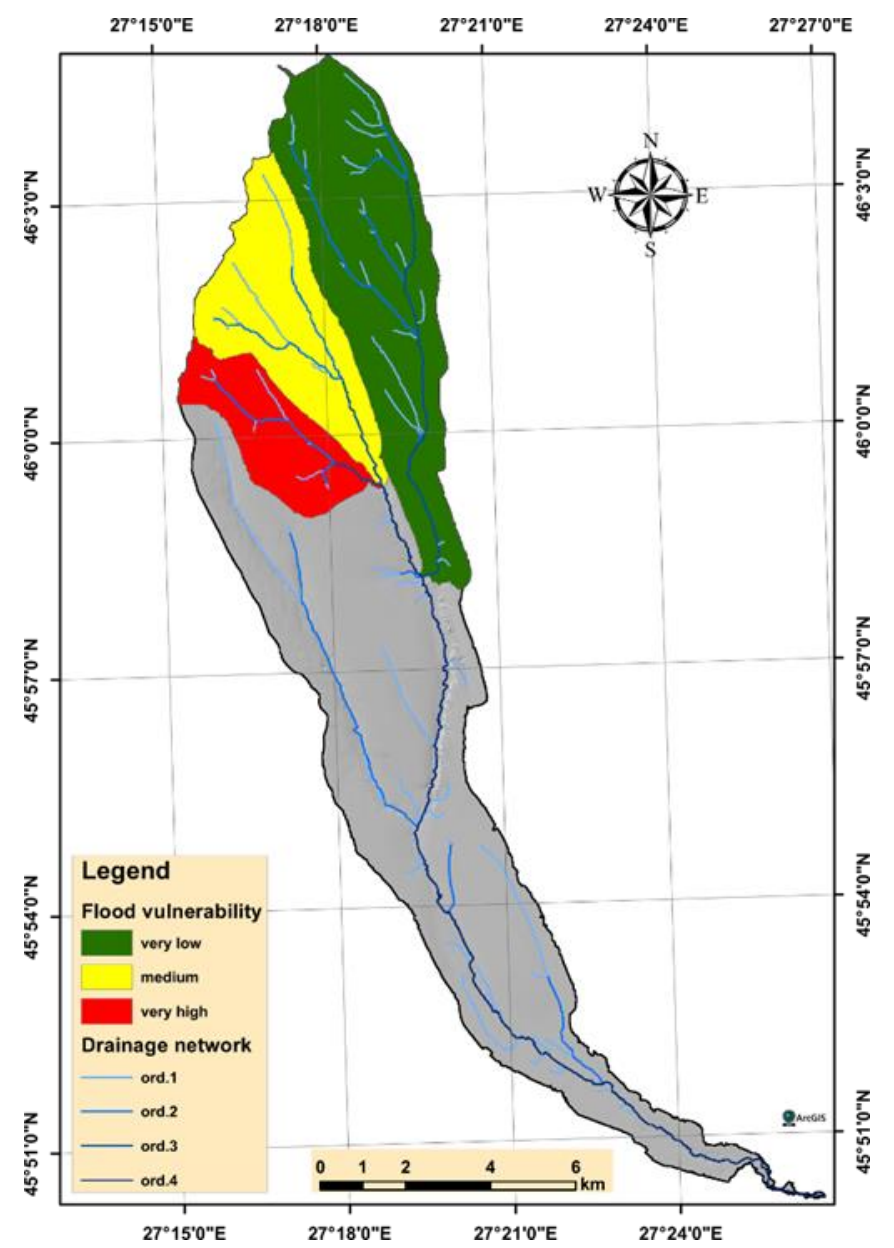

Figure 4. The flood vulnerability of sub-basins of order III in Tecucel drainage basin

The last cartographic material represents the flood vulnerability of the sub-basins of order III (Fig. 4). As it can be observed, the sub-basin classified as having very low flood vulnerability occupies the largest area of all three and at the same time has a high drainage density but it is very elongated, which means that a flood could hardly form in this area due to the difficulties of rainwater to simultaneously concentrate into a flash flood. The sub-basin classified as having a medium flood vulnerability, compared to the previous one, has a less dense drainage network and is smaller in size, but it has a shape that supports the formation of a flood, because in a basin shaped in this manner, the water from upstream tributaries reaches the main channel at once, meaning a high peak flow that can create an overbank flow.

A river that has a basin with high Circularity Ratio also has the characteristic of having tributaries with similar values of length, this meaning that in case of a heavy rain, the rainwater that reach the tributaries will be able to flow into the main channel at similar time intervals, generating a high volume of water, that would flow into the main river which would create a high peak flood. An interesting example can be given by the river classified by a very high vulnerability to flood, being situated on an area with steep slopes, having a wider opening in the downstream area, a dense drainage network and a small area, where the flow from the tributaries could rapidly concentrate into the main channel 
and generating a flash flood in a small interval of time, due to the proximity of the large area to the confluence.

\section{CONCLUSIONS}

The analysis described and applied in this paper used a comparative, multi-parameter methodology to identify the flood vulnerability at a basinal and sub-basinal level, in Tecucel hydrographic basin, using GIS techniques. The parameters used, that are of most relevance for this study, were Circularity Ratio, Elongation Ratio, Drainage Density, Stream Frequency, Relief Ratio, Ruggedness and Bifurcation Ratio. Alongside with the LiDAR Digital Elevation Model, the results of the analysis were significant and relevant. This method of analyzing the flood vulnerability can take into account other parameters as well, such as vegetation cover, soil type, land cover etc., but a proportion of minimum 7-8 parameters must be kept in order to have significant and reliable results.

Concerning the data used and the results, it can be considered that this method, while using relatively little input, can offer an insight of the hydrological vulnerability in a watershed, with a degree of precision in accordance to the input data used and the chosen parameters. In conclusion, based in the data used and the results obtained, this method represents a useful tool in the analysis of vulnerability to floods.

\section{ACKNOWLEDGEMENT}

This work was financially supported by the Department of Geography from the "Alexandru Ioan Cuza" University, of Iasi, and the infrastructure was provided through the POSCCE-O 2.2.1, SMIS-CSNR 13984-901, No. 257/28.09.2010 Project, CERNESIM.

\section{REFERENCES}

[1] Romanescu G., Hapciuc O.E., Minea I. \& Iosub M. Flood vulnerability assessment in the mountain-plateau transition zone: a case study of Marginea village (Romania), Journal of Flood Risk Management, vol. 11, issue S1, 2018.

[2] Romanescu G. \& Stoleriu C. Causes and effects of the catastrophic flooding on the Siret River (Romania) in July-August 2008, Natural Hazards, Springer, vol. 69, no. 3, pp. 1351-1367, 2013.

[3] Flood R.L. Complexity: A definition by construction of a conceptual framework. Systems Research and Behavioral Science, vol. 4, no. 3, pp. 177-185, 1987.

[4] Romanescu G. \& Nistor I. The effect of the July 2005 catastrophic inundations in the Siret River's Lower Watershed, Romania, Natural Hazards, vol. 57, no. 2, pp. 345-368, 2011.

[5] Enea A. Metode si tehnici moderne de cuantificare a vulnerabilitatii la inundatii in bazinul hidrografic Tazlau, PhD Thesis, Alexandru Ioan Cuza University, pp. 192, 2017.

[6] Iosub M., Tomasciuc A.I., Hapciuc O.E. \& Enea A. Flood risk analysis in Suceava city, applied for it's main river course, Geobalcanica Proceedings 2016, pp. 111-118, 2016.

[7] Albu M, Stoleriu C.C., Enea A, Iosub M., Hapciuc O.E. \& Romanescu G. Geomorfologic risk assessement in Tecucel drainage basin, using GIS techniques, Geobalcanica Proceedings 2016, pp. 95-102.

[8] Zaharia L., Catang S., Craciun E. \& Toroimac G. Flood vulnerability of Tecuci city: the role of natural and socioeconomic factors, Revista Riscuri si catastrofe, vol. 7, no. 5, pp. 130-140, 2008. 
[9] Raber G.T., Jensen J.R., Hodgson M.E., Tullis J.A., Davis B.A. \& Berglund J. Impact of LiDAR nominal post-spacing on DEM accuracy and flood zone delineation. Photogrammetric engineering \& remote sensing, vol. 73, no. 7, pp. 793-804, 2007.

[10] Haile A.T. \& Rientjes T.H.M. Effects of LiDAR DEM resolution in flood modelling: a model sensitivity study for the city of Tegucigalpa, Honduras. Isprs wg iii/3, iii/4, vol. 3, pp. 12-14, 2005.

[11] Romanescu G. Backwater as hydrological hazard. Study case: Suhu catchment (Romania). International Multidisciplinary Scientific Geoconference SGEM 2015, Water Resources. Forest, Marine and Ocean Ecosystem, Conference Proceedings, Hydrology\&Water Resources, vol. 1, pp. 95-102, 2015. DOI: 10.5593/SGEM2015/B31/S12.013

[12] Romanescu G., Jora I. \& Stoleriu C. The most important high floods in Vaslui river basin causes and consequences, Carpathian Journal of Earth and Environmental Sciences, vol. 6, no. 1, pp. 119-132, 2011.

[13] Romanescu G., Stoleriu C. \& Romanescu A.M. Water reservoirs and the risk of accidental flood occurrence. Case study: Stanca-Costesti reservoir and the historical floods of the Prut river in the period July-August 2008, Romania, Hydrological Processes, vol. 25, no. 13, pp. 20562070, 2011.

[14] Romanescu G., Zaharia C. \& Stoleriu C. Long-term changes in average annual liquid flow river Miletin (Moldavian Plain), Carpathian Journal of Earth and Environmental Sciences, vol. 7, no. 1, pp. 161-170, 2012.

[15] Romanescu G. Alluvial Transport Processes and the Impact of Anthropogenic Intervention on the Romanian Littoral of the Danube delta, Ocean \& Coastal Management, vol. 73, pp. 31-43, 2013.

[16] Miftode I.D. \& Romanescu G. Exceptional flash floods in the Uz hydrographic basin - causes and consequences, Proceedings, 2nd International Scientific Conference GEOBALCANICA 2016, 10-12 June, 2016, Skopje, Republic of Macedonia, pp. 33-42, 2016. Doi:10.18509/GBP.2016.05.

[17] Romanescu G. \& Stoleriu C. An inter-basin backwater overflow (the Buhai Brook and the Ezer reservoir on the Jijia River, Romania), Hydrological Processes, vol. 28, no. 7, pp. 31183131, 2013.

[18] Romanescu G. \& Stoleriu C. Anthropogenic interventions and hydrological-risk phenomena in the fluvial-maritime delta of the Danube (Romania), Ocean \& Coastal Management, vol. 102, pp. 123-130, 2014.

[19] Mierla M., Romanescu G., Nichersu I. \& Grigoras I. Hydrological risk map for the Danube delta - a case study of floods within the fluvial delta, IEEE Journal of Selected Topics in Applied Earth Observations and Remote Sensing, vol. 8, no. 1, pp. 98-104, 2015.

[20] Cojoc G., Romanescu G. \& Tirnovan A. Exceptional floods on a developed river. Case study for the Bistrita River from the Eastern Carpathians (Romania), Natural Hazards, vol. 77, no. 3, pp. 1421-1451, 2015.

[21] Hapciuc O.E., Romanescu G., Minea I., Iosub M., Enea A. \& Sandu I. Flood susceptibility analysis of the cultural heritage in the Sucevita catchment (Romania), International Journal of Conservation Science, vol. 7, no. 2, pp. 501-510, 2016.

[22] Romanescu G. \& Stoleriu C. Exceptional floods in the Prut basin, Romania, in the context of heavy rains in the summer of 2010, Natural Hazards and Earth System Sciences, vol. 17, pp. 381-396, 2017.

[23] Romanescu G., Cimpianu C.I., Mihu-Pintilie A. \& Stoleriu C.C. Historic flood events in NE Romania (post-1990), Journal of Maps, vol. 13, no. 2, pp. 787-798, 2017. 
[24] Hapciuc O.E., Iosub M., Tomasciuc A.I., Minea I. \& Romanescu G. Identification of the potential risk areas regarding the floods occurrence within small mounatin catchments, Proceedings, 2nd International Scientific Conference GEOBALCANICA 2016, 10-12 June, 2016, Skopje, Republic of Macedonia, pp. 177-184, 2016. Doi: 10.18509/GBP.2016.24.

[25] Romanescu G., Mihu-Pintilie A., Stoleriu C.C., Carboni D., Paveluc L.E. \& Cimpianu C.I. A Comparative Analysis of Exceptional Flood Events in the Context of Heavy Rains in the Summer of 2010: Siret Basin (NE Romania) Case Study. Water, vol. 10, no. 2, 216, pp. 1-17, 2018.

[26] Zavoianu I. Morphometry of drainage basins, 1st ed. Amsterdam, Elsevier, 1985.

[27] Horton R.E. Erosional development of streams and their drainage basins; hydrophysical approach to quantitative morphology, Geological society of America bulletin, vol. 56, no. 3, pp. 275-370, 1945. 